\title{
АНТИОКСИДАНТНО-ПРООКСИДАНТНИЙ БАЛАНС У ТКАНИНІ ПЕЧІНКИ В ДИНАМЦІ СКЕЛЕТНОЇ, ЧЕРЕПНО-МОЗКОВОЇ ТРАВМ ТА ЇХ ПОСДНАННЯ У ПЕРІОД РАННІХ ПРОЯВІВ ТРАВМАТИЧНОЇ ХВОРОБИ
}

\begin{abstract}
У дослідах на щурах-самцях з'ясовували роль антиоксидантно-прооксидантних порушень у патогенезі скелетної, черепно-мозкової травм та їх поєднання. Тварин було поділено на контрольну та три дослідних групи. У 1-й дослідній групі моделювали скелетну травму шляхом нанесення дозованого удару по кожному стегну спеціальним пристроєм із досягненням закритого перелому, в 2-й - закриту черепно-мозкову травму середнього ступеня тяжкості, у 3-й - ці травми поєднували. Через 1, 3 i 7 діб після нанесення травми за умов тіопентало-натрієвого знеболювання тварин виводили з експерименту методом тотального кровопускання із серця. У гомогенаті печінки щурів визначали вміст ТБК-активних продуктів ПОЛ, активність каталази та розраховували антиоксидантнопрооксидантний індекс: каталаза/ТБК-активні продукти ПОЛ. Результати досліджень показали, що за умов модельованих травм у період ранніх проявів травматичної хвороби істотно збільшується вміст у тканині печінки ТБК-активних продуктів ПОЛ, який досягає максимуму через 7 діб. При цьому суттєво знижується активність каталази в гомогенаті печінки. У результаті антиоксидантнопрооксидантний індекс зміщується в бік наростання прооксидантних механізмів. Звертає на себе увагу той факт, що виявлені порушення на тлі черепно-мозкової травми були подібними до аналогічних при поєднаній травмі й суттєво перевищували результати, отримані при самій скелетній травмі, що свідчить про велику роль пошкодження черепа і мозку в патогенезі поєднаного ураження.
\end{abstract}

КЛЮЧОВІ СЛОВА: скелетна травма, черепно-мозкова травма, метаболізм печінки.

ВСТУП. Травматизм належить до найскладніших медичних і соціальних проблем сучасності [9]. В осіб працездатного віку він став основною причиною смерті, випередивши серцево-судинні та онкологічні захворювання. у загальній структурі травм найчастіше виникають пошкодження кінцівок (85-90%), черепа і хребта (50-72 \%) [6].

При дії травмувального чинника значної сили виникають тяжкі множинні (в межах однієї анатомічної ділянки) та поєднані пошкодження (в різних анатомічних ділянках). За цих умов спостерігають порушення, зумовлені локалізацією пошкодження, а також викликані дисфункцією органів і систем, віддалених від місця травмування, які трактують як травматичну хворобу (TX) [11].

Одним із провідних механізмів системних проявів TX та розвитку органної дисфункції $€$ інтенсифікація пероксидного окиснення ліпідів (ПОЛ) $[4,10]$, яка тісно пов'язана з рівнем системної відповіді організму на запалення [5].

๑ І. А. Михайлюк, В. М. Михайлюк, 2015.
В роботах окремих авторів показано порушення інтенсивності ПОЛ і антиоксидантного захисту в тканині нирки під впливом скелетної, черепно-мозкової (ЧМТ) травм та їх поєднання [11], однак у тканині печінки ці процеси вивчено недостатньо. Враховуючи значний функціональний взаємозв'язок цих органів детоксикації, можна припустити подібність системних механізмів ураження нирок і печінки, що вимагає спеціального дослідження.

Метою даної роботи було з'ясувати роль антиоксидантно-прооксидантних порушень у патогенезі скелетної, черепно-мозкової травм та їх поєднання.

МЕТОДИ ДОСЛІДЖЕННЯ. Експерименти виконано на 90 нелінійних білих щурах-самцях масою 180-200 г, які перебували на стандартному раціоні віварію. Тварин було поділено на чотири групи: контрольну (інтактні щури) та три дослідних. У 1-й дослідній групі моделювали скелетну травму шляхом нанесення дозованого удару по кожному стегну спеціаль- 
ним пристроєм із досягненням закритого перелому [13], в 2-й - моделювали закриту ЧМТ середнього ступеня тяжкості за методикою, описаною в роботі [7], у 3-й - ці травми поєднували. Усі експерименти проводили за умов тіопентало-натрієвого знеболювання (40 мг·К $\Gamma^{-1}$ маси).

Через 1, 3 і 7 діб після нанесення травми за умов тіопентало-натрієвого знеболювання тварин виводили з експерименту методом тотального кровопускання із серця. У гомогенаті печінки визначали вміст ТБК-активних продуктів ПОЛ [2], активність каталази [12] та розраховували антиоксидантно-прооксидантний індекс (АПІ): каталаза/ТБК-активні продукти ПОЛ [3].

Статистичну обробку результатів виконано у відділі системних статистичних досліджень ДВНЗ “Тернопільський державний медичний університет імені І. Я. Горбачевського МОЗ України" з використанням критерію Манна-Уітні в програмному пакеті Statsoft STATISTICA.

РЕЗУЛЬТАТИ Й ОБГОВОРЕННЯ. ЯК ВИДНО з таблиці 1, за умов скелетної травми вміст у тканині печінки ТБК-активних продуктів ПОЛ через 1 добу посттравматичного періоду, порівняно з контрольною групою, підвищувався на 26,0 \%, через 3 доби - на 27,6 \%, через 7 діб досягав максимального рівня - на 43,3 \%. У всі ці терміни результат був статистично достовірним $(p<0,05)$. При ЧМТ результат виявився подібним - на 35,4, 37,4 і 53,1 \% відповідно $(p<0,05)$. Найбільше зростання величини досліджуваного показника спостерігали після нанесення поєднаної краніоскелетної травми - на 38,6, 42,9 і 72,4 \% відповідно $(p<0,05)$.

Порівнюючи дослідні групи між собою, з'ясували, що вміст ТБК-активних продуктів
ПОЛ у тканині печінки через 1 і 3 доби між дослідними групами практично не відрізнявся $\left(p_{1-2}>0,05 ; p_{1-3}>0,05 ; p_{2-3}>0,05\right)$. Через 7 діб він суттєво переважав у групі тварин із поєднаною травмою: порівняно зі скелетною травмою на $20,3 \%\left(p_{1-3}<0,05\right)$, ЧМТ - на $12,6 \%$ $\left(p_{2-3}<0,05\right)$.

Аналізуючи динаміку досліджуваного показника, встановили, що за умов усіх експериментальних травм вміст у тканині печінки ТБК-активних продуктів ПОЛ інтенсивно зростав до 1-ї доби, до 3-ї - перебував на цьому ж рівні, проте до 7-ї повторно підвищувався, що було істотно більшим порівняно з попередніми термінами спостереження $(p<0,05)$.

Як видно з таблиці 2, активність каталази у тканині печінки під впливом модельованих травм істотно знижувалася порівняно з контрольною групою. Після нанесення скелетної травми через 1 добу показник ставав меншим на 27,2 \%, через 3 доби - на 41,5 \%, через 7 діб - на 32,5 \% (p<0,05); ЧМТ - на 30,6, 36,7 і 46,9 \% відповідно $(p<0,05)$; поєднаної травми - на 33,4, 42,0 і 51,3 \% відповідно $(p<0,05)$.

Порівнюючи дослідні групи між собою, з'ясували, що через 1 і 3 доби показник так само між дослідними групами практично не відрізнявся $\left(p_{1-2}>0,05 ; p_{1-3}>0,05 ; p_{2-3}>0,05\right)$. Через 7 діб на тлі скелетної травми він виявився статистично достовірно більшим, ніж після нанесення черепно-мозкової і поєднаної травм (відповідно, на 27,1 \%, $\mathrm{p}_{1-2}<0,05$ і 38,6\%, $\left.\mathrm{p}_{1-3}<0,05\right)$. Звертає на себе увагу той факт, що через 7 діб посттравматичного періоду активність каталази у тканині після моделювання черепно-мозкової і поєднаної травм була найнижчою і практично однаковою $(p>0,05)$.

Аналіз динаміки досліджуваного показника показав, що у групі тварин із скелетною травмою показник досягав мінімального рівня

Таблиця 1 - Вміст ТБК-активних продуктів пол у тканині печінки (мкмоль·кг-1)

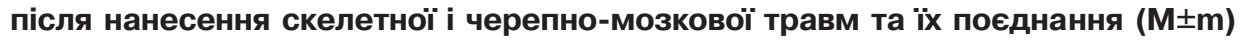

\begin{tabular}{|c|c|c|c|c|}
\hline \multirow{2}{*}{ Вид травми } & \multirow{2}{*}{ Контроль } & \multicolumn{3}{|c|}{ Тривалість посттравматичного періоду } \\
\hline & & 1 доба & 3 доби & 7 діб \\
\hline Скелетна & \multirow[t]{3}{*}{$\begin{array}{c}2,54 \pm 0,09 \\
(n=6)\end{array}$} & $\begin{array}{c}3,20 \pm 0,10^{*} \\
(\mathrm{n}=8)\end{array}$ & $\begin{array}{c}3,24 \pm 0,08^{\star} \\
(n=10)\end{array}$ & $\begin{array}{c}3,64 \pm 0,09^{*} \\
(n=10)\end{array}$ \\
\hline Черепно-мозкова & & $\begin{array}{c}3,44 \pm 0,13^{\star} \\
(n=8)\end{array}$ & $\begin{array}{c}3,49 \pm 0,14^{\star} \\
(n=10)\end{array}$ & $\begin{array}{c}3,89 \pm 0,12^{*} \\
(n=9)\end{array}$ \\
\hline Поєднана & & $\begin{array}{c}3,52 \pm 0,13^{*} \\
(n=8)\end{array}$ & $\begin{array}{c}3,63 \pm 0,14^{\star} \\
(n=9)\end{array}$ & $\begin{array}{c}4,38 \pm 0,16^{*} \\
(n=8)\end{array}$ \\
\hline \multicolumn{2}{|c|}{$p_{1-2}$} & $>0,05$ & $>0,05$ & $>0,05$ \\
\hline \multicolumn{2}{|c|}{$p_{1-3}$} & $>0,05$ & $>0,05$ & $<0,05$ \\
\hline \multicolumn{2}{|c|}{$p_{2-3}$} & $>0,05$ & $>0,05$ & $<0,05$ \\
\hline
\end{tabular}

Примітки. Тут і в таблицях 2 та 3:

1. * - відмінності стосовно контрольної групи статистично достовірні $(p<0,05)$.

2. $p_{1-2}$ - достовірність відмінностей показника між групами тварин із скелетною та черепно-мозковою травмами; $\mathrm{p}_{1-3}-$ між скелетною та поєднаною травмами; $\mathrm{p}_{2-3}$ - між черепно-мозковою та поєднаною травмами. 
Таблиця 2 - Активність каталази у тканині печінки (мккат·кг'-1)

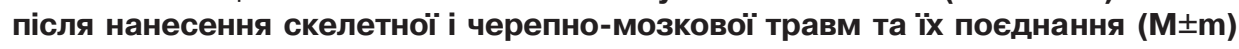

\begin{tabular}{|c|c|c|c|c|}
\hline \multirow{2}{*}{ Вид травми } & \multirow{2}{*}{ Контроль } & \multicolumn{3}{|c|}{ Тривалість посттравматичного періоду } \\
\hline & & 1 доба & 3 доби & 7 діб \\
\hline Скелетна & \multirow[t]{3}{*}{$\begin{array}{c}0,431 \pm 0,034 \\
(n=6)\end{array}$} & $\begin{array}{c}0,314 \pm 0,011^{*} \\
(n=8)\end{array}$ & $\begin{array}{c}0,252 \pm 0,014^{\star} \\
(n=10)\end{array}$ & $\begin{array}{c}0,291 \pm 0,010^{*} \\
(n=10)\end{array}$ \\
\hline Черепно-мозкова & & $\begin{array}{c}0,299 \pm 0,008^{*} \\
(n=8)\end{array}$ & $\begin{array}{c}0,273 \pm 0,013^{*} \\
(n=10)\end{array}$ & $\begin{array}{c}0,229 \pm 0,009^{*} \\
(n=9)\end{array}$ \\
\hline Поєднана & & $\begin{array}{c}0,287 \pm 0,010^{*} \\
(n=8)\end{array}$ & $\begin{array}{c}0,250 \pm 0,015^{\star} \\
(n=9)\end{array}$ & $\begin{array}{c}0,210 \pm 0,008 * \\
(n=8)\end{array}$ \\
\hline \multicolumn{2}{|c|}{$p_{1-2}$} & $>0,05$ & $>0,05$ & $<0,05$ \\
\hline \multicolumn{2}{|c|}{$p_{1-3}$} & $>0,05$ & $>0,05$ & $<0,05$ \\
\hline \multicolumn{2}{|c|}{$p_{2-3}$} & $>0,05$ & $>0,05$ & $>0,05$ \\
\hline
\end{tabular}

через 3 доби після нанесення травми, що виявилося статистично достовірно меншим, ніж через 1 добу $(p<0,05)$. Через 7 діб він зростав і ставав суттєво більшим, ніж через 3 доби ( $p<0,05)$. За умов ЧМТ і поєднаної травми динаміка активності каталази у тканині печінки була подібною: показник поступово знижувався з 1-ї до 7-ї доби і ставав істотно меншим, ніж через 1 і 3 доби ( $<<0,05)$.

У свою чергу, величина АПІ (табл. 3) на тлі скелетної, черепно-мозкової травм та їх поєднання в усі терміни спостереження була істотно меншою, ніж у контрольній групі $(p<0,05)$. Після нанесення самої скелетної травми показник досягав мінімального рівня через 3 доби (45,3 \%) і залишався на такому ж до 7-ї доби, після моделювання ЧМТ він знижувався і досягав мінімального рівня через 7 діб (34,9 \% стосовно контролю). Після нанесення поєднаної травми величина АПІ зменшувалась аналогічно до самої черепномозкової травми, проте з більшою амплітудою. Через 7 діб показник становив 27,9% від рівня контролю $(p<0,05)$.

Порівнюючи дослідні групи між собою, з'ясували, що через 1 добу показник виявився істотно меншим у групі тварин з поєднаною краніоскелетною травмою, ніж у щурів із самою скелетною травмою (на 16,2 \%, $\mathrm{p}_{1-3}<0,05$ ). При цьому між дослідними групами тварин 3 ізольованою травмою він був статистично не достовірним ( $\left.p_{1-2}>0,05 ; p_{2-3}>0,05\right)$.

Через 3 доби посттравматичного періоду не відмічали істотних відмінностей між дослідними групами, в яких моделювали різні травми ( $\left.p_{1-2}>0,05 ; p_{1-3}>0,05 ; p_{2-3}>0,05\right)$, проте через 7 діб величина АПІ зменшувалася від скелетної до черепно-мозкової і поєднаної травм. Відмінності між дослідними групами були статистично достовірними $\left(\mathrm{p}_{1-2}<0,05\right.$; $\left.\mathrm{p}_{1-3}<0,05 ; \mathrm{p}_{2-3}<0,05\right)$.

Отримані результати свідчать про те, що, незважаючи на походження травм, інтенсифікація процесів ліпопероксидації і виснаження антиоксидантного захисту в тканині печінки є провідними механізмами ТХ у їі ранній період. Системна гіпоксія, яка виникає на основі травматичного шоку, є пусковим механізмом ініціації утворення активних форм кисню в органах шлунково-кишкового тракту [1]. Останні згубно діють на клітинні мембрани з розвитком цитолізу та загибеллю клітин, що, у свою чергу, ініціює синтез і вивільнення запальних медіаторів - про- і протизапальних цитокінів, які активують лейкоцити, макрофаги й ендотеліальні клітини. За таких умов для нейтралізації патогенного чинника знову виділяються активні форми кисню, які при надмірному утворенні зумовлюють значне ендотеліальне пошкодження з поглибленням порушення

Таблиця 3 - Динаміка величини АПІ в тканині печінки (ум. од.) після нанесення скелетної і черепно-мозкової травм та їх поєднання (M $\pm \mathrm{m})$

\begin{tabular}{|c|c|c|c|c|}
\hline \multirow{2}{*}{ Вид травми } & \multirow{2}{*}{ Контроль } & \multicolumn{3}{|c|}{ Тривалість посттравматичного періоду } \\
\hline & & 1 доба & З доби & 7 діб \\
\hline Скелетна & \multirow[t]{3}{*}{$\begin{array}{c}0,172 \pm 0,017 \\
(n=6)\end{array}$} & $\begin{array}{c}0,099 \pm 0,004^{*} \\
(n=8)\end{array}$ & $\begin{array}{c}0,078 \pm 0,003^{*} \\
(n=10)\end{array}$ & $\begin{array}{c}0,080 \pm 0,002^{*} \\
(n=10)\end{array}$ \\
\hline Черепно-мозкова & & $\begin{array}{c}0,088 \pm 0,005^{\star} \\
(n=8)\end{array}$ & $\begin{array}{c}0,079 \pm 0,005^{\star} \\
(n=10)\end{array}$ & $\begin{array}{c}0,060 \pm 0,004^{*} \\
(n=9)\end{array}$ \\
\hline Поєднана & & $\begin{array}{c}0,083 \pm 0,005^{\star} \\
(n=8)\end{array}$ & $\begin{array}{c}0,070 \pm 0,006^{*} \\
(n=9)\end{array}$ & $\begin{array}{c}0,048 \pm 0,001^{*} \\
(n=8)\end{array}$ \\
\hline \multicolumn{2}{|c|}{$p_{1-2}$} & $>0,05$ & $>0,05$ & $<0,05$ \\
\hline \multicolumn{2}{|c|}{$\mathrm{p}_{1-3}$} & $<0,05$ & $>0,05$ & $<0,05$ \\
\hline \multicolumn{2}{|c|}{$p_{2-3}$} & $>0,05$ & $>0,05$ & $<0,05$ \\
\hline
\end{tabular}


функції органів і тканин [14, 15]. При цьому джерелом надходження активних форм кисню та інших ендотоксинів є пошкоджені м'які тканини і кістки кінцівок, а також тканини черепа та мозку. За глибиною порушення антиоксидантно-прооксидантного балансу домінують черепно-мозкова і поєднана травми порівняно із самою скелетною. Можна припустити, що при ЧМТ відіграє роль також і порушення нейрогормональної регуляції, про що йдеться в роботі [8].

Таким чином, черепно-мозкова і поєднана травми в період ранніх проявів травматичної хвороби супроводжуються більшим переважанням прооксидантних механізмів у тканині печінки, особливо через 7 діб посттравматичного періоду, порівняно зі скелетною, що має вагоме значення в патогенезі порушення функції гепатоцитів і розвитку печінкової недостатності.
ВИСНОВКИ. 1. у період ранніх проявів травматичної хвороби після моделювання скелетної і черепно-мозкової травм та їх поєднання суттєво зростає інтенсивність ліпідної пероксидації у тканині печінки на тлі виснаження антиоксидантного захисту, що проявляється істотним збільшенням вмісту ТБКактивних продуктів ПОЛ, зниженням активності каталази та зміщенням величини АПІ в бік переважання прооксидантних механізмів.

2. Інтенсивність порушень зростає з 1-ї до 7-ї доби експерименту і більша на тлі черепномозкової та поєднаної травм порівняно із самою скелетною.

Перспективи подальших досліджень. Отримані результати спрямовані на поглиблене вивчення ефективності антиоксидантної терапії в корекції системних порушень за умов тяжкої травми.

\section{СПИСОК ЛІТЕРАТУРИ}

1. Агаджанян В. В. Шок - положительные и отрицательные аспекты при политравме / В. В. Агаджанян // Политравма. - 2007. - № 1. - С. 5-8.

2. Андреева Л. И. Модификация метода определения перекисей липидов в тесте с тиобарбитуровой кислотой / Л.И.Андреева, Л.А.Кожемякин, А. А. Кишкун // Лаб. дело. - 1988. - № 11. - С. 41-43.

3. Антиоксидантно-прооксидантний індекс сироватки крові щурів з експериментальним стоматитом і його корекція зубними еліксирами / А. П. Левицький, В. М. Почтар, О. А. Макаренко, Л. І. Гридіна // Одес. мед. журн. - 2006. - № 1. - С. 22-25.

4. Борис Р. М. Особливості пероксидного окиснення ліпідів у період гострої реакції на поєднану краніо-скелетну травму / Р. М. Борис // Актуал. пробл. трансп. медицины. - 2013. - № 2 (32). C. $149-153$.

5. Генинг Т. П. Показатели перекисного окисления липидов и антиоксидантной защиты в системе "сыворотка крови - эритроцит" при острой циркуляторной гипоксии / Т. П. Генинг, Д. А. Ксейко // Усп. совр. естествознания. - 2004. - № 4. - С. 17-20.

6. Гуманенко Е. К. Достижения в лечении тяжелой сочетанной травмы за последние 20 лет / Е. К. Гуманенко, А. Б. Сингаевский // Скорая мед. помощь. - 2004. - 5, № 3. - С. 153-154.

7. Ельский В. Н. Моделирование черепномозговой травмы / В. Н. Ельский, С. В. Зяблицев. Донецк : Новый мир, 2008. - 140 с.

8. Ельский В. Н. Нейрогормональные регуляторные механизмы при черепно-мозговой травме / В. Н. Ельский, С. В. Зяблицев. - Донецк : Новый мир, 2008. - 240 c.
9. Ельский В. Н. Патофизиология, диагностика и интенсивная терапия тяжелой черепно-мозговой травмы / В. Н. Ельский, А. М. Кардаш, Г. А. Городник ; под ред. В. И. Черния. - Донецк : Новый мир, 2004. $200 \mathrm{c.}$.

10. Козак Д. В. Особливості показників пероксидного окиснення ліпідів в динаміці раннього і пізнього періодів політравми / Д. В. Козак // Актуал. пробл. трансп. медицини. - 2012. - № 3. - С. 103106.

11. Мерлєв Д. І. Особливості антиоксидантнопрооксидантного стану кіркового шару нирки в умовах скелетної, черепно-мозкової травм та їх поєднання / Д. І. Мерлєв, А. А. Гудима // Здобутки клініч. і експерим. медицини. - 2013. - № 2. С. $140-142$.

12. Метод определения активности каталазы / М. А. Королюк, Л. И. Иванова, И. Г. Майорова, В. Е. Токарев // Лаб. дело. - 1988. - № 1. - С. 16-19.

13. Придруга С. М. Порушення гуморальної ланки імунітету в період пізніх проявів політравми та його корекція тіотриазоліном / С. М. Придруга, Р. М. Борис // Буковин. мед. вісн. - 2013. - 17, № 1 (65). - C. 96-101.

14. Die Behan dlung des hemorrhagischen Schocks / W. G. Voelckel, A. von Goedecke, D. Fries [et al.] // Der Andsthesist. - 2004. - 53. - P. 11511167.

15. Surviving Sepsis Campaign Management Guidelines Committee. Surviving Sepsis Campaign guidelines for management of severe sepsis and septic shock / R. P. Dellinger, J. M. Carlet, H. Masur [et al.] // Crit. Care Med. - 2004. - 32, № 3. - P. 858-873. 


\title{
АНТИОКСИДАНТНО-ПРООКСИДАНТНЫЙ БАЛАНС В ТКАНИ ПЕЧЕНИ В ДИНАМИКЕ СКЕЛЕТНОЙ, ЧЕРЕПНО-МОЗГОВОЙ ТРАВМ И ИХ СОЧЕТАНИЯ В ПЕРИОД РАННИХ ПРОЯВЛЕНИЙ ТРАВМАТИЧЕСКОЙ БОЛЕЗНИ
}

\begin{abstract}
Резюме
В опытах на крысах-самцах выясняли роль антиоксидантно-прооксидантных нарушений в патогенезе скелетной, черепно-мозговой травм и их сочетания. Животные были разделены на контрольную и три опытных группы. В 1-й опытной группе моделировали скелетную травму путем нанесения дозированного удара по каждому бедру специальным устройством с достижением закрытого перелома, во 2-й - закрытую черепно-мозговую травму средней степени тяжести, в 3-й эти травмы совмещали. Через 1, 3 и 7 суток после нанесения травмы в условиях тиопенталонатриевого обезболивания животных выводили из эксперимента методом тотального кровопускания из сердца. В гомогенате печени крыс определяли содержание ТБК-активных продуктов ПОЛ, активность каталазы и рассчитывали антиоксидантно-прооксидантный индекс: каталаза/ТБК-активные продукты ПОЛ. Результаты исследований показали, что в условиях моделируемых травм в период ранних проявлений травматической болезни существенно увеличивается содержание в ткани печени ТБК-активных продуктов ПОЛ, которое достигает максимума через 7 суток. При этом существенно снижается активность каталазы в гомогенате печени. В результате антиоксидантно-прооксидантный индекс смещается в сторону нарастания прооксидантных механизмов. Обращает на себя внимание тот факт, что выявленные нарушения на фоне черепно-мозговой травмы были подобны аналогичным при сочетанной травме и существенно превышали результаты, полученные при самой скелетной травме, что свидетельствует о большой роли повреждения черепа и мозга в патогенезе сочетанного поражения.
\end{abstract}

КЛЮЧЕВЫЕ СЛОВА: скелетная травма, черепно-мозговая травма, метаболизм печени.

I. A. Mykhaylyuk, V. M. Mykhaylyuk I. YA. HORBACHEVSKY TERNOPIL STATE MEDICAL UNIVERSITY

\section{ANTIOXIDANT-PROOXIDANT BALANCE IN THE LIVER TISSUE IN THE DYNAMICS OF A SKELETAL, CRANIAL-CEREBRAL TRAUMAS AND THEIR COMBINATION IN THE PERIOD OF EARLY SIGNS OF THE TRAUMATIC DISEASE}

\section{Summary}

In experiments on male rats clarifying the role of antioxidant-prooxidant in the pathogenesis of skeletal disorders, traumatic brain injuries and their combinations. The animals were divided into 4 groups: control and three experimental. In the first experimental group we modeled a skeletal trauma by means of striking a dosed blow with obtaining a closed fracture of the both femurs, in the second one - we modeled a closed CCT of a medium type of complexity, in the third one - these traumas were combined. After 1, 3 and 7 days after striking the trauma in the conditions of Sodium-thiopental anesthesia, the animals were taken out the experiment by the method of a total phlebotomy of the heart. In liver homogenate were tested TBA-active products of lipid peroxidation, catalase activity and antioxidant-expected proksydantnyy Index (API), catalase / TBA-active products of lipid peroxidation. The researches showed that in the conditions of the modeled traumas in the period of the early signs of TD the contents of TBA-active products of the $L P O$ is growing substantially and reaches maximum after 7 days. In these conditions the catalase activity in the liver homogenate lowers substantially. Consequently, API displaces towards the side of the prooxidant mechanisms accumulation. The fact that attracts attention is that discovered irregularities on the background of CCT were similar to the analogous ones in case of a combined trauma and exceeded substantially the results, obtained with the skeletal trauma itself which affirms about the significant contribution of the skull and brain injury into the pathogenesis of the combined wound.

KEY WORDS: skeletal trauma, traumatic and brain injury, liver metabolism. 